\title{
Exercise of Leadership by Nurse Leaders of a Class Entity from 1926 to 1974
}

\author{
Exercício da Liderança de 1926 a 1974 por Enfermeiras Dirigentes de uma Entidade \\ de Classe \\ Ejercicio del Liderazgo de 1926 a 1974 por Enfermeras Líderes de una Entidad de Clase
}

Ana Lúcia Domingues Neves*; Maria Cristina Sanna**

\begin{abstract}
Background: The exercise of Nursing leadership begins with an understanding that leading means keeping the team members united in the quest for the accomplishment of professional goals. In the pioneer class entity for the representation of Brazilian Nursing - the Brazilian Association of Nursing (ABEn) - the advancement of the professional class was directly linked to the efforts of its leaders.

Objectives: To describe the exercise of leadership by nurse leaders of the ABEn.

Methodology: Documentary historical study, with a qualitative approach, on the leadership of the nurse leaders of the ABEn from 1926 to 1974. The primary sources were scientific publications of Brazilian journals, as well as case studies, biographies and obituaries of the nursing leaders.

Results: The analysis of the lives of these nurses allowed us to build the following outcome categories: preparation for leadership, ideological positioning of the leaders, exercise of leadership, and professional recognition of the leaders.

Conclusion: We conclude that the leaders had political power and working capacity. They were role models of dedication and firmness of conviction, with great capacity for coordination and political power. They did great things for nursing.
\end{abstract}

Keywords: history of nursing; leadership; nurses; biography

\section{Resumo}

Contexto: O exercício da liderança em enfermagem iniciou-se com a compreensão de que liderar é manter os membros da equipe unidos na busca pela realização dos objetivos profissionais. $\mathrm{Na}$ entidade de classe pioneira na representação da enfermagem brasileira - Associação Brasileira de Enfermagem (ABEn) - a ascensão da classe profissional estava diretamente ligada aos esforços das suas dirigentes.

Objetivos: Descrever o exercício da liderança por enfermeiras dirigentes da ABEn.

Metodologia: Estudo qualitativo, histórico documental, sobre a liderança daquelas que atuaram, no período de 1926 a 1974 , na direção da ABEn. As fontes primárias foram publicações científicas de periódicos brasileiros, além de estudos de casos, biografias e obituários da história das líderes da enfermagem.

Resultados: A análise das histórias dessas enfermeiras permitiu construir as seguintes categorias de resultados: preparação para a liderança, posicionamento ideológico das líderes, exercício da liderança e reconhecimento profissional das líderes.

Conclusão: As líderes tinham poder político, capacidade de trabalho, eram modelo de dedicação, firmeza de convicção, com grande capacidade de articulação, e poder político; muito realizaram pela enfermagem.

Palavras-chave: história da enfermagem; liderança; enfermeiras; biografia

\footnotetext{
* RN, Specialist in Cardiology and Continuous. Education Student of the Postgraduate Program Stricto Sensu of the College of Nursing of the Federal University of São Paulo. Contribution to the Stricto Sensu of the College of Nursing of the Federal University of São Paulo. Contribution to the
article: literature review, data collection and analysis, article writing. Address for correspondence: article: literature review, data collection and analysis, article writing. Address for correspondence:
Rua Sena Madureira, 1500, CEP:04021-001, Vila Clementino, São Paulo, Brasil [analudneves@ Rua Sena $\mathrm{M}$.
gmail.com]

gmail.com]. Researcher of the GEPAG, São Paulo, Brazil [mcsanna@uol.com.br] Contribution to the article: research design and planning, methodology review, data interpretation, final approval of the version to be published.
}

\section{Resumen}

Contexto: El ejercicio del liderazgo de enfermería comenzó con la comprensión de que liderar es mantener a los miembros del equipo unidos en la búsqueda de la realización de metas profesionales. En la entidad de clase pionera en la representación de la enfermería brasileña - la Asociación Brasileña de Enfermería (ABEn) - el ascenso de la clase profesional estaba directamente vinculado a los esfuerzos de sus líderes.

Objetivos: Describir el ejercicio del liderazgo de las enfermeras líderes de la ABEn.

Metodología: Estudio cualitativo, histórico documental, sobre el liderazgo de aquellas que actuaron en el período de 1926 a 1974 en la dirección de la ABEn. Las fuentes primarias fueron publicaciones científicas de las revistas brasileñas, así como estudios de casos, biografías y obituarios de la historia de las líderes de enfermería.

Resultados: El análisis de las historias de esas enfermeras permitió construir las siguientes categorías de resultados: preparación para el liderazgo, posicionamiento ideológico de las líderes, ejercicio del liderazgo y reconocimiento profesional de las líderes.

Conclusión: Las líderes tenían poder político y capacidad de trabajo, eran modelo de dedicación, tenían firmeza de convicción, gran capacidad de articulación y poder político, hicieron mucho por la enfermería.

Palabras clave: historia de la enfermería; liderazgo; enfermeras; biografía

Received for publication: 05.08 .15

Accepted for publication: 06.01 .16 


\section{Introduction}

The pioneer entity class in the representation of Brazilian nursing - the Brazilian Association of Nursing (ABEn) - celebrated its $88^{\text {th }}$ anniversary in 2015 and, according to Cabral and Almeida (2013), its trajectory was marked by leaders with great capacity for dialogue, coordination and leadership, which resulted in its growing participation in the promotion of the scientific and professional development of nursing in the country. The advancement of the professional class was directly related to the efforts of those $20^{\text {th }}$-century leaders who, through their interventions as entity leaders, achieved major victories in various fields of action in Brazil based on the accumulation of ideas and continuity of the work plans (Carvalho, 2008).

The institution under analysis had renowned personalities, similarly to other associations from other countries. In Portugal, for example, Mariana Diniz de Sousa has left her mark in the History of Nursing through her actions in an entity class (Ordem dos Enfermeiros, 2015).

One of the transformations occurred throughout the trajectory of the ABEn is its different designation over the course of 85 years: Associação Nacional de Enfermeiras Diplomadas (National Association of Graduate Nurses; ANED, 1926-1944), Associação Brasileira de Enfermeiras Diplomadas (Brazilian Association of Graduate Nurses; ABED, 1944-1954), and Associação Brasileira de Enfermagem (Brazilian Nursing Association; ABEn, 1954 until today; Cabral \& Almeida, 2013), which denotes the power of the political coordination of its leaders. This activity has defined a profile of nurse leaders capable of developing management with a spirit of innovation and entrepreneurship (Mendes \& Marziale, 2003), a strong political position, knowledge, and the ability to deal with contentious and controversial issues (Furukawa, 2009), as well as a concern to come together, through the participation in class entities, to face the challenges of the nursing profession.

The exercise of nursing leadership is begins with an understanding that leading means keeping the team members united through dialogue (Sousa \& Barroso, 2009), in the quest for accomplishing professional goals. In this regard, we can find a parallel with the performance of the former leaders of the entity under analysis, who tried to implement the ideas arising from previous administrations, in order to strengthen the class achievements. Thus, the following question arises: How did the leaders of the ABEn exercise leadership?

By understanding the need to contribute with reflections on leadership in Brazilian nursing, today built under a new paradigm, and to engage in its construction, we developed this study with the purpose of describing the exercise of leadership by nurse leaders of the ABEn between 1926 and 1974.

\section{Methodology}

A documentary historical study, with a qualitative approach, was conducted on the leadership of the leaders of the ABEn between 1926 and 1974. The primary sources were scientific publications in Brazilian journals, many from the leaders themselves, as well as case studies, biographies and obituaries of the nurse leaders. The oldest text dates back to 1958 and the most current one to 2013. As secondary sources, we used books, theses and dissertations on the topic.

The study focused on the time period between 1926 and 1974 , i.e. from the foundation of the entity to its consolidation, which is attested by the last mandate documented in the official publication of the ABEn. It was in this period that several graduate nurses acted in several domains and stood out in the constitution of professional nursing in Brazil. This served as a basis for selecting the nurses here analyzed: Edith de Magalhaes Fraenkel, Hilda Anna Krisch, Zaira Cintra Vidal, Marina Bandeira de Oliveira, Waleska Paixão, Glete de Alcântara, Maria Rosa de Souza Pinheiro, Marina de Andrade Rezende, Clarice Della Torre Ferrarini, Circe De Melo Ribeiro and Amália Corrêa de Carvalho, who occupied the head position of entity management in the analyzed timeframe (Carvalho, 2008).

The following words were selected from the Health Sciences Descriptors of the Virtual Health Library (VHL) and used in the search: História da Enfermagem (History of Nursing), Liderança (Leadership), Enfermeiras (Nurses), Biografia (Biography), Enfermagem (Nursing) and Assistência de Enfermagem (Nursing Care). In addition, other key conceptual terms were also used for the search: lideres (leaders), líder (leader) and líder da equipe (team leader). 
The inclusion criteria of the primary sources were as follows: Being written in Portuguese, being available in full-text online or in printed form, being stored in research centers available for consultation, and addressing the exercise of leadership by the nurse leaders under study.

The access to the sources used for the search required no previous authorization from the Research Ethics Committee, unlike the cases of research with human beings and/or animals, because we had free online access or consulted the published sources.

The articles were selected through a search in the following databases: PeriEnf of the College of Nursing of the University of São Paulo (USP), those that integrate the BVS portal, and those in the virtual library Scientific Electronic Library Online (SciELO). In relation to text location, 11 articles (50\%) were found in the Perienf database, $10(40.9 \%)$ in the BVS (in the databases LILACS, MEDLINE, BDENF, and Hisa) and one article (9.10\%) was found in the SCIELO library. A total of 22 articles were found. The selection of duplicated articles was based on the Perienf database, because it provides older articles, which are highly important for historic research.

Data were organized and physically stored in folders, in chronological order of publication date. For the organization of the study population, a worksheet was drawn up in Microsoft Office Excel software, with the following variables: database, title, journal, year of publication, author(s), and topics addressed in each publication.

The articles were found in full text in the different sources. Those only available for copying (electrostatic or scanned copies) were obtained in the Library Wanda de Aguiar Horta of the USP College of Nursing, in a total of 12 texts. The other 10 texts were obtained online in PDF format and printed to facilitate analysis. For the data analysis according to the historic method, the material was repeatedly read in full and thematically categorized. The contents were grouped by themes to build the following categories of description: preparation for leadership, professional roles of leadership, characterization of the leaders' profile, professional recognition of the leaders, and leadership in the organization of nursing services.

The results and the discussion were presented in a descriptive way aiming to answer the question posed at the beginning of the study. All categories were explained in the light of historical events and compared to accounts on the exercise of leadership from the leaders of the ABEn.

\section{Results and Discussion}

\section{Preparation for Leadership}

The former leaders of the ABEn were trained in renowned nursing schools in the country and abroad, and many of them received scholarships from the Rockefeller Foundation, through the International Health Service, which is an international agency that supported the organization of a profession capable of associating education and health (Moreira, 1999). According to Furukawa (2009), at that time, the Rockefeller Foundation offered them training abroad, already with the intention of training nurses under the paradigm of the Anglo-American nursing model developed in the United States of America (USA), which would come to prevail in the Americas.

This fact marked the history of education and preparation of the former leaders of the ABEn for positions of leadership, in several health areas, after receiving training in education institutions such as the University of Toronto, Canada (Oguisso, 2002, 2003) and the University of Philadelphia in the USA (Anonymous, 2002; Oguisso, Freitas, \& Takashi, 2013), as well as after completing traineeships and financed courses at renowned institutions in the USA (Borenstein, Padilha, Caetano, \& Mancia, 2004), France and Canada, in addition to post-graduation courses in Nursing Administration and Teaching (Oguisso, 2002; Oguisso et al., 2013) in New York, USA, and the Master's Degree at the University of Columbia, in the USA (Oguisso, 2002, 2003).

This phenomenon occurred mainly after 1922, with the creation of the Nurses' Service of the National Public Health Department, followed by the foundation of the Anna Nery Nursing School (EEAN) in 1923, and continued until 1933, with the creation of the Nursing School Carlos Chagas (EECC; Furukawa, 2009). We would like to underline that, between 1920 and 1960, the nurses who excelled in their courses or professional activities in Brazil were also sent to study in the abovementioned countries with the purpose of preparing them for managing schools and nursing services in public health institutions, which were positions of great responsibility, and, gradually, 
replacing the North-American and European nurses from the American Technical Mission (Missão Técnica Americana; Carvalho, 2008).

\section{Ideological Positioning of the Leaders}

The profile of the former leaders of the ABEn can be clearly described, since there are common features in their professional and personal characteristics. The correct, clear, demanding and concise language in the right measure, a unique personality, as well as the example of simplicity were reflected in the grandeur of the actions of such leaders (Secaf, 1988), who always led a professional life with many missions and special endeavors (Oguisso, 2002), large-scale projects for which they were convened, and which they performed with success.

Despite the much effort and dedication necessary for the exercise of nursing leadership, the former leaders, according to Alcântara (1960), benefited from an inquiring, disciplined and visionary profile, and had the ability to create opportunities to express their points of view, aiming to build professional Nursing. Many of them were recognized as great leaders of Brazilian nursing, either though their important political intervention (Oguisso, 2002, 2003) or their courage, determination, boldness (Oguisso, 2002), intelligence, dedication and endless work capacity. They knew how to express their thoughts with clarity and rationality, were clear-sighted, wise and, above all, had a secure and visionary leadership (Borenstein et al., 2004).

The profile of the former leaders of the ABEn was said to be visionary because they valued the importance of a class association for professional development; active because they helped, for example, organizing nursing scientific events, such as the 1st Brazilian Nursing Congress; and, finally, political because of their strategic actions such as the Survey on Nursing Resources and Needs in Brazil (Borenstein et al., 2004). This successful leadership was also associated with the ability to rally the team around their ideals, which allowed them to exercise long-term leadership in the history of Brazilian nursing (Mancial \& PadilhaII, 2006). Thus, the power of communication of the former leaders of the ABEn, together with the capacity to act objectively in divergent situations (Oguisso, 2003), built a leadership profile capable of mediating important achievements for Brazilian nursing.

\section{Professional Recognition of the Leaders}

The professional recognition of the nurse leaders demonstrated the importance of their work in favor of the class, which was being visibly leveraged by their capacity for political coordination expressed in the achievements for the class. These leaders were constantly searching for the recognition and assimilation of the profession to the quality levels at the time and, due to their important actions, they made it possible for Nursing to become a structured profession.

At that time, according to Oguisso, Campos, and Santiago (2009), this recognition was manifested through awards, honorable mentions and titles, such as the Award of Nurse of the Year. This award was a tribute to prominent leaders such as the one who broke with the doubly stigmatized ideals of nurse and professor, becoming a professionally successful, independent, woman who stood for her principles and her condition as a woman.

Therefore, many former leaders of the ABEn received the honorable mention of this award (Oguisso, 2003; Pinheiro, 1969; Alcântara, 1960; Oguisso et al., 2009; Ferrarini, 1968). It should be noted that the $1^{\text {st }}$ Award of Nurse of the Year in 1967 was given to the leader who published various articles in national and international journals, receiving several awards for her work presented in nursing events (Azevedo, Carvalho, \& Gomes, 2009; Ferrarini, 1968).

Another recognition was the granting of the title of honorary member of the Associação Nacional de Enfermeiras Diplomadas (ANED) to the first Brazilian nurse who had a vast cultural capital, similar to that of American nurses, and was able to leverage the feminist movement for Brazilian nursing (Mancial \& PadilhaII, 2006). The title of Doctor Honoris Causa, only granted by EEAN, was granted to the leader who addressed the State of Sergipe for a social cause and contributed with the creation of schools, kindergartens and hospitals, through her political influence (Azevedo et al., 2009). She was one of the nurses who exercised leadership through example in the ABEn.

\section{Exercise of Leadership}

The professional roles of leadership of the former leaders of the ABEn were of great importance for the consolidation of professional nursing, such as the intervention in the $1^{\text {st }}$ Presidency of the 
Federal Nursing Council (COFEN; Oguisso, 2003), the support in the organization of the $1^{\text {st }}$ Brazilian Nursing Congress (CBEn; Oguisso, 2002; Oguisso et al., 2013). Between 1969 and 1971, the 21 ${ }^{\text {st }}, 22^{\text {nd }}, 23^{\text {rd }}$ and $24^{\text {th }} \mathrm{CBE}$ were held in the cities of Porto Alegre, São Paulo, Manaus and Belo Horizonte, respectively (Carvalho, 2008).

In relation to the exercise of leadership, the leaders were also committed to planning, organizing, implementing and completing the Survey on Nursing Resources and Needs in Brazil, which was the first study conducted with a scientific methodology in Brazilian nursing (Oguisso, 2002, 2003).

In the period under study, the first Brazilian graduate nurses started to assume the leadership of the profession, intervening in various domains such as support and governmental associations. Ribeiro (1965) describes accounts stating that one of the former leaders of the ABEn argued that the leadership of the nursing team depended on the nurse's availability and a decrease of bureaucratic tasks.

Clearly, the nurses' administrative work in health institutions was greatly appreciated, which influenced the implementation of the Clinics Hospital of the Faculty of Medicine of the University of São Paulo (HCFMUSP) and the USP College of Nursing, as well as the leaders' performance as assistants and, later, as leaders in the Subdivision of Nursing of that institution (Pinheiro, 1969; Borenstein et al., 2004).

The political positioning of the leaders at that time allowed the law that established the nurse as a senior technical-scientific professional in the Federal Public Service to be sanctioned, while it also boosted Nursing to the university level, with the corresponding remuneration (Carvalho, 2008; Azevedo et al., 2009).

In this context, the consolidation of professional nursing was a priority for these leaders, who considered that, for the profession to be established, there should be a school, an association and a journal. Thus, there are reports that, in the mandate of one of the leaders of the ABEn, in 1971, work was resumed to constitute other professional associations.

The leaders also played a predominant and active role in the creation, implementation and management of the ABEn. According to Carvalho (2008), one of them was even appointed, in 1947, to represent the entity in the commission created to study the nursing problems in Brazil.
With the consolidation of the profession still in mind, they helped to idealize the journal Revista Anais de Enfermagem and, in 1966, the Marina Andrade Rezende fund was created to provide financial aid to the Brazilian Journal of Nursing (Carvalho, 2008). Another aspect of the exercise of leadership can be observed in the planning of the undergraduate and post-graduate courses, with one of the leaders also providing advisory services to the Portuguese Ministry of Health for the development of post-graduate courses for nurses in Portugal (ManciaI \& PadilhaII, 2006; Oguisso et al., 2009).

The awareness of the need to train empowered and specialized nursing professionals also had an impact on the History of Nursing in Portugal, because there are reports of concern with the lack of harmony between the curricula used to train nurses, who, at that time, were admitted without any preparation and the necessary qualifications for the professional practice. In addition, the creation of a journal was a visionary issue in Portugal, because, according to Rodrigues and Louçano (2014), there was already a fortnightly journal being published in 1929 - O Enfermeiro Português (the Portuguese Nurse).

Within the scope of Brazilian nursing education, there was yet another type of manifestation of the exercise of leadership. One of the leaders was the interim manager of the National Public Health Department, and created the Rachel Haddock Lobo School, while others were vice-directors and/or directors of the current Nursing College of the Federal University of São Paulo (EEUSP), whose foundations were also built on the work of these leaders (Oguisso, 2002; Alcântara, 1960; Oguisso et al., 2009).

Different segments of the Brazilian healthcare services, public bodies and institutions were affected by the exercise of leadership of the former leaders of the ABEn, as for example, the Ministry of Health, the Superintendence of the HCFMUSP and ABEn itself during the creation of the Belo Horizonte and the São Paulo Sections (Ferrarini, 1968; Oguisso et al., 2013). In this period, in the Anna Nery School of Nursing, another leader also stood out in the field of education, and was soon appointed, by the country's President, as director of that institution, which marked the moment when the school was defined as an example to be followed (Azevedo et al., 2009) by the remaining schools. In 1971, in the mandate of one of the leaders of the ABEn, the study of a new minimum curriculum 
project was forwarded to the Federal Education Council, resulting in Opinion No. 163/72 (Carvalho, 2008), which governed Nursing education until 1994. Many other achievements described by Mancial and Padilhall (2006), such as the title of honorary member of the entity, the position of instructor at the Anna Nery School of Nursing, as well as its incorporation into the Federal University of Rio de Janeiro (UFRJ) were merits obtained by one of the former leaders of the ABEn.

\section{Conclusion}

By reflecting on the path taken by the leaders to achieve important positions of political coordination, and by unveiling their ideology in the search for the professionalization of Nursing - the creation of quality schools, representative class associations and scientific journals - this study allowed us to better understand the historical trajectory of the exercise of leadership.

We concluded that the leaders had political power and great capacity for work, were committed to education and were models of dedication and firmness of conviction, in addition to being committed to defending the class. Among the personal and professional characteristics evident in the exercise of leadership of the Brazilian nursing leaders, the following stood out: the use of a correct, clear, concise and demanding language; a unique personality; the simplicity in the grandeur of their actions; an inquiring, disciplined, and visionary profile, as well as a forward-looking view and ability to create opportunities. The leaders of the ABEn had significant political involvement, determination, boldness, intelligence, dedication, and capacity for work. They expressed their thoughts with clarity and rationality, lucidity, foresight and wisdom, exercising a secure and visionary leadership, without digressions. The study involving important leaders of the class entity - who were considered legitimate case studies in the history of Nursing leadership - can contribute to building new knowledge to support the modulation of the behavior of professional groups through the correlation of this experience between the past and the present of Nursing.

\section{References}

Alcântara, G. (1960). Preparo de enfermeiras para o campo de enfermagem em saúde pública, administração de enfermaria e ensino e supervisão na Escola de Enfermagem de Ribeirão Preto. Revista Brasileira de Enfermagem, 13(2), 201-229.

Anónimo (2002). Edith de Magalhaes Fraenkel. Revista Brasileira de Enfermagem, 55(3), 269

Azevedo, J. M., Carvalho, V., \& Gomes, M. L. (2009). Waleska Paixão: Uma biografia a serviço da enfermagem brasileira. Revista da Escola de Enfermagem Anna Nery, 13(1), 31-35. doi: 10.1590/\$1414-81452009000100005

Borenstein, M. S., Padilha, M. I., Caetano, T. L., \& Mancia, J. R. (2004). Hilda Anna Krisch: Pioneira na enfermagem catarinense: Formação e contribuição. Revista Brasileira de Enfermagem, 57(3), 366-370. doi: 10.1590/S003471672004000300024

Cabral, I. E., \& Almeida, A. J. (2013). 85 anos de ABEn e 80 de REBEn promovendo o desenvolvimento científico e profissional da enfermagem brasileira. Revista Brasileira de Enfermagem, 66(esp.),13-23. doi: 10.1590/S0034-71672013000700002

Carvalho, A. C. (2008). Associação Brasileira de Enfermagem, 1926-1976: Documentário (2a ed.). Brasília, Brasil: Aben Nacional.

Ferrarini, C. D. (1968). Apresentação da enfermeira do ano. Revista Brasileira de Enfermagem, 21(4), 163-165.

Furukawa, P. O. (2009). Comparativo de personagens da história da enfermagem brasileira. Revista de Enfermagem da Escola Anna Nery, 13(2), 402-405. doi: 10.1590/\$141481452009000200023

Ordem dos Enfermeiros (Ed.). (2015). Liderar em Saúde, construir alternativas: Livro de resumos do IV Congresso da Ordem dos Enfermeiros. Lisboa, Portugal: Autor.

ManciaI, J. R., \& PadilhaII, M. I. (2006). Trajetória de Edith Magalhães Fraenkel. Revista Brasileira de Enfermagem, 59(Esp.),432-437. doi: 10.1590/S0034-71672006000700009

Mendes, I. A., \& Marziale, M. H. (2003). Uma trajetória de trabalho e sucesso. Revista Latino Americana de Enfermagem, 11(1),1-6. doi: 10.1590/S0104-11692003000100001

Moreira, M. C. (1999). A Fundação Rockefeller e a construção da identidade profissional de enfermagem no Brasil na primeira república. Revista História, Ciências, Saúde de Manguinhos, 5(3), 621-645. doi: 10.1590/S0104-59701999000100005

Oguisso, T. (2002). Tributo a grande líder Maria Rosa Souza Pinheiro. Revista Paulista de Enfermagem, 21(2), 113-114. doi: 10.1590/\$0034-71672003000100016

Oguisso, T. (2003). Maria Rosa Sousa Pinheiro: A grande líder da enfermagem. Revista Brasileira de Enfermagem, 56(1), 7678. doi: 10.1590/S0034-71672003000100016 
Oguisso, T., Campos, P. F., \& Santiago, E. S. (2009). Maria Rosa Sousa Pinheiro e a reconfiguração da enfermagem brasileira. Revista Texto e Contexto Enfermagem, 18(4), 643-651. doi: 10.1590/S0104-07072009000400005

Oguisso, T., Freitas, G. F., \& Takashi, M. H. (2013). Edith de Magalhaes Fraenkel: O maior vulto da enfermagem brasileira. Revista da Escola de Enfermagem da USP, 47(5),1227-1234. doi: 10.1590/S0080-623420130000500029

Ribeiro, C. M. (1965). Organização de um serviço de enfermagem hospitalar. Revista Brasileira de Enfermagem, 18(5), 495505.
Rodrigues, M. A., \& Louçano, C. (2014). Documento ad usum et beneficium: Revista O Enfermeiro Português: 1929-1930. Revista de Enfermagem Referência, 4(1),163-169. doi: 10.12707/RIV14000

Secaf, V. (1988). Maria Rosa Sousa Pinheiro: Personalidade marcante. Revista da Escola de Enfermagem da USP, 22(3), 255.

Sousa, L. B., \& Barroso, M. G. (2009). Reflexão sobre o cuidado como essência da liderança em enfermagem. Revista de Enfermagem da Escola Anna Nery, 13(1),181-187. doi: 10.1590/S1414-81452009000100025 
